\title{
PENANGGULANGAN TINDAK PIDANA PERDAGANGAN ORANG DI MALUKU
}

\author{
Yonna Beatrix Salamor \\ Program Studi Ilmu Hukum, Universitas Pattimura, Ambon \\ Email: yonnahukum@gmail.com
}

\begin{abstract}
Human trafficking is a crime against human rights and dignity which by the country of Indonesia are protected by both the Pancasila and the 1945 Constitution. Human trafficking is increasing due to how profitable it is to the perpetrators. In fact, according to the United Nations, human trafficking is the most profitable organized crime and is related to money laundering, drug trafficking, document forging and human smuggling. Human trafficking in Indonesia has 3 general forms, namely migrant workers, domestic helpers and commercial sex workers. As the 3rd poorest province, Maluku is not spared from the problem of human trafficking. The lack of job vacancies, high number of job seekers, and the number of the impoverished in Maluku are some of the factors that encourage the crime of human trafficking. The purpose of the study is to find out how the crime is handled and the countermeasures against the crime of human trafficking in Maluku. In this study, the method used is juridical empirical, and in addition, researchers also conducted interviews and data collection in institutions related to this study. Based on the research conducted, the population of Maluku Province in 2016 was 1,715,548 people with uneven distribution due to population concentration in certain regions, especially in the downtown area and other concentrated regions. Poverty is one of the contributors to the crime of human trafficking in Maluku, with the number of the impoverished in Maluku in 2014 reaching 307,000. In Maluku, the forms of human trafficking often carried out include the recruitment of minimum wage workers placed in the palm oil and cocoa plantation sector, the fisheries sector involving foreign workers, and the prostitution industry involving women and girls.
\end{abstract}

Keywords: Countermeasures, Human Trafficking, Maluk

\begin{abstract}
ABSTRAK
Perdagangan orang merupakan kejahatan terhadap hak asasi manusia, harkat dan martabat seseorang yang oleh negara Indonesia dilindungi baik dalam Pancasila maupun Undang-Undang Dasar 1945. Perdagangan orang semakin banyak karena keuntungan yang diperoleh pelaku sangat besar. Bahkan menurut PBB, perdagangan orang adalah sebuah perusahaan kriminal yang paling menguntungkan dan terkait dengan pencucian uang, perdagangan narkoba, pemalsuan dokumen dan penyelundupan manusia. Masalah perdagangan orang di Indonesia memiliki 3 bentuk umum yaitu buruh migran, pembantu rumah tangga dan pekerja seks komersial. Sebagai propinsi termiskin ke-3 Maluku juga tidak luput dari permasalahan perdagangan orang. Kurangnya lapangan pekerjaan, tingginya angkatan pencari kerja, dan jumlah penduduk miskin di Maluku merupakan beberapa faktor yang mendorong tindak pidana perdagangan orang. Tujuan penelitian untuk mengetahui penanganan dan penanggulangan tindak pidana pergdangan orang di Maluku. Dalam penelitian ini, metode yang digunakan adalah yuridis empiris, selain itu peneliti juga melakukan wawancara dan pengambilan data di instansi-instansi yang berkaitan dengan penelitian ini. Berdasarkan penelitian yang dilakukan, maka jumlah penduduk Propinsi Maluku tahun 2016 berjumlah 1.715.548 jiwa dengan pesebaran yang tidak merata karena adanya konsentrasi penduduk pada wilayah-wilayah tertentu terutama pada wilayah pusat kota dan terkonsentrasi pada wilayah-wilayah tertentu. Kemiskinan merupakan salah satu faktor penyebab terjadinya tindak pidana perdagangan orang di Maluku dengan data penduduk miskin Maluku tahun 2014 sebesar 307.000 jiwa. Di Maluku, bentuk tindak pidana perdagangan orang yang sering dilakukan yaitu perekrutan tenaga kerja dengan upah minim yang ditempatkan pada sektor perkebunan kelapa sawit maupun coklat, sektor perikanan yang melibatkan tenaga kerja asing dan industri prostitusi yang melibatkan perempuan dan anak perempuan.
\end{abstract}

Kata kunci: Penanggulangan, Perdagangan Orang, Maluku

\section{PENDAHULUAN}

\section{Latar Belakang}

Perdagangan orang merupakan kejahatan terhadap hak asasi manusia, harkat dan martabat seseorang yang oleh negara Indonesia dilindungi baik dalam Pancasila maupun Undang-Undang Dasar 1945. Dapat dikatakan perdagangan orang sebagai bentuk modern dari perbudakan. Perdagangan orang adalah tindakan perekrutan, pengangkutan, penampungan, pengiriman, 
pemindahan, atau penerimaan seseorang dengan ancaman kekerasan, penggunaan kekerasan, penculikan, penyekapan, pemalsuan, penipuan, penyalahgunaan kekuasaan, atau posisi rentan yang memegang kendali atas orang lain tersebut baik yang dilakukan di dalam negara maupun antar negara untuk tujuan eksploitasi atau mengakibatkan orang tereksploitasi.

Perdagangan orang semakin banyak karena keuntungan yang diperoleh pelaku sangat besar. Bahkan menurut $\mathrm{PBB}$, perdagangan orang adalah sebuah perusahaan kriminal yang paling menguntungkan dan terkait dengan dengan pencucian uang, perdagangan narkoba, pemalsuan dokumen dan penyelundupan manusia. Menurut hasil studi ILO keuntungan yang diperoleh dari perempuan, laki-laki dan anak-anak yang diperdagangkan diperkirakan mencapai US\$ 32 miliar setiap tahunnya. Keuntungan yang diambil dari pekerja paksa yang diperdagangkan itu setiap orangnya kurang lebih US\$ 13. Sehingga, dalam satu tahun keuntungan yang diperoleh bisa mencapai US\$ 32 miliar.

Indonesia adalah salah satu negara yang memiliki masalah dalam tindak pidana perdagangan orang. Pemahaman masyarakat tentang tindak pidana perdagangan orang sangat berhubungan dengan kesadaran hukum. Kesadaran hukum tidak hanya berupa pemahaman tentang aturan yang terdapat dalam hukum positif, tetapi lebih pada implementasi aturan hukum tersebut. Perdagangan orang berkembang pada kondisi masyarakat yang memiliki ekonomi lemah, pemahaman agama atau moral yang kurang dengan berbagai modus operandi yang dipakai.

Masalah perdagangan orang di Indonesia memiliki 3 (tiga) bentuk umum yang selalu menjadi sorotan, yaitu: Buruh Migran; Pembantu Rumah Tangga; dan Pekerja Seks Komersial

Sebagian besar warga negara Indonesia yang bekerja di luar negeri, disalurkan melalui agen-agen tenaga kerja illegal (tidak resmi). Data LSM (Lembaga Swadaya Masyarakat) memperkirakan 1,42,1 juta buruh migran (tenaga kerja Indonesia) yang bekerja di luar negeri. Bentuk kedua yaitu pembantu rumah tangga berdasarkan laporan dari ILO (International Labour Organization) 23\% dari pembantu rumah tangga di Indonesia adalah anak-anak. Sedangkan, untuk pekerja seks komersial (PSK) di Indonesia mencapai 130.000-240.000 dan 30\% pekerja seks komersial adalah anak-anak.

Maluku adalah propinsi yang sebagian besar wilayahnya terdiri dari lautan juga tidak luput dari tindak pidana perdagangan orang. Sebagai propinsi termiskin ke-3 di Indonesia, berikut adalah presentase penduduk miskin di Propinsi Maluku menurut Kabupaten/Kota dari tahun 2010- 2014:

Tabel 1

Sumber: BPS Provinsi Maluku

\begin{tabular}{lccccc}
\hline \multirow{2}{*}{ Kabupaten/Kota } & \multicolumn{5}{c}{ Presentase Penduduk Miskin } \\
\cline { 2 - 6 } & 2010 & 2011 & 2012 & 2013 & 2014 \\
\hline Maluku Tenggara Barat & 33.93 & 30.13 & 28.45 & 29.75 & 28.56 \\
Maluku Tenggara & 30.70 & 27.16 & 26.03 & 25.06 & 24.21 \\
Maluku Tengah & 28.41 & 25.15 & 24.05 & 22.15 & 21.41 \\
Buru & 24.82 & 22.00 & 19.78 & 18.51 & 17.55 \\
Kepulauan Aru & 34.96 & 30.96 & 28.57 & 27.34 & 26.33 \\
Seram Bagian Barat & 30.08 & 26.70 & 25.35 & 24.63 & 23.79 \\
Seram Bagian Timur & 31.44 & 27.94 & 25.92 & 24.49 & 23.40 \\
Maluku Barat Daya & 39.22 & 34.49 & 32.55 & 29.25 & 28.33 \\
Buru Selatan & 21.82 & 19.33 & 18.29 & 17.05 & 16.59 \\
Kota Ambon & 7.67 & 6.83 & 5.98 & 4.42 & 4.23 \\
Kota Tual & 32.01 & 28.17 & 25.66 & 23.28 & 22.31 \\
& 25.32 & 22.45 & 20.76 & 19.27 & 18.44 \\
\hline
\end{tabular}


Kurangnya lapangan pekerjaan, tingginya angkatan pencari kerja, dan jumlah penduduk miskin yang ada di Maluku merupakan beberapa faktor yang mendorong munculnya tindak pidana perdagangan orang di Propinsi Maluku.

\section{METODE PENELITIAN}

Metode Penelitian adalah tata cara bagaimana suatu penelitian akan dilaksanakan. Mengingat penelitian ini merupakan penelitian hukum, maka metode penelitian yang digunakan adalah metode penelitian hukum. Penelitian hukum merupakan proses untuk menemukan aturan hukum, prinsip-prinsip hukum maupun doktrin-doktrim hukum untuk menjawab isu-isu hukum yang dihadapi (Peter Mahmud Marzuki:35). Untuk menunjang penelitian ini maka penulis mempergunakan metode penelitian:

a. Jenis Penelitian. Penelitian tentang Penanggulangan Tindak Pidana Perdagangan Orang di Maluku adalah penelitian Yuridis Empiris. Penelitian Yuridis Empiris adalah suatu metode penelitian hukum yang berfungsi untuk melihat hukum dalam artian nyata dan meneliti bagaimana bekerjanya hukum di lingkungan masyarakat. Dikarenakan dalam penelitian ini meneliti orang dalam hubungan hidup di masyarakat maka metode penelitian hukum empiris dapat dikatakan sebagai penelitian hukum sosiologis. Dapat dikatakan bahwa penelitian hukum yang diambil dari fakta-fakta yang ada di dalam suatu masyarakat, badan hukum atau badan pemerintah.

b. Tipe Penelitian. Adapun tipe penelitian yang digunakan adalah deskriptif analitis yaitu memberikan gambaran terhadap objek yang diteliti melalui data atau sampel dan diolah atau dianalisis untuk diambil kesimpulannya (Sugiyono:29).

c. Lokasi Penelitian. Dalam penelitian ini, lokasi yang digunakan sebagai lokasi penelitian adalah Provinsi Maluku. Provinsi Maluku terdiri dari 11 Kabupaten/Kota. Oleh karena itu yang dipilih sebagai lokasi penelitian adalah Kota Ambon. Kabupaten Seram Bagian Barat, dan Kabupaten Kepulauan Aru.

d. Sumber Data. Dalam penelitian ini, jenis data yang digunakan adalah data primer yang dihasilkan dari penelitian lapangan yang diperoleh langsung dari responden penelitian yang terkait dengan tindak pidana perdagangan orang. Dengan mengadakan studi/penelitian kepustakaan akan memperoleh data awal untuk dipergunakan dalam penelitian lapangan, dan data sekunder yang diperoleh dari penelitian kepustakaan terdiri dari:

1). Bahan Hukum Primer, berkaitan dengan masalah yang akan diteliti seperti UndangUndang Nomor 21 Tahun 2007 tentang Pemberantasan Tindak Pidana Perdagangan Orang.

2). Bahan Hukum Sekunder, merupakan bahan hukum yang memberikan penjelasan dan petunjuk mengenai bahan hukum primer seperti buku-buku referensi, jurnal hukum dan hasil-hasil penelitian karya ilmiah yang relevan dengan penelitian ini.

3). Bahan Hukum Tertier, sebagai bahan hukum penunjang yang mencakup petunjukpetunjuk maupun penjelasan terhadap bahan hukum primer dan sekunder yaitu berupa kamus, ensiklopedia.

e. Teknik Pengumpulan Data. Pengumpulan data yang penulis lakukan dengan dua cara yaitu:

1). Penelitian Kepustakaan, yaitu pengumpulan data sekunder baik berupa peraturan perundang-undangan yang berlaku dan dokumen yang berkaitan dengan objek yang diteliti maupun teori-teori dan asas-asas hukum yang berkaitan dengan materi penelitian. 
2). Penelitian Lapangan, yaitu pengumpulan data secara langsung dari pihak-pihak terkait dengan tindak pidana narkotika agar memperoleh dan menghimpun data primer atau data yang relevan dengan objek yang akan diteliti.

f. Teknik Analisa Data. Data penelitian diolah dan dianalisis secara kualitatif yaitu menganalisa data berdasarkan kualitasnya lalu dideskripsikan dengan menggunakan katakata sehingga diperoleh bahasan atau paparan dalam bentuk kalimat yang sistematis dan dapat dimengerti, kemudian ditarik kesimpulan.

\section{HASIL DAN PEMBAHASAN}

\section{a. Gambaran Sosial Kependudukan di Propinsi Maluku}

Propinsi Maluku merupakan salah satu wilayah kepulauan di Indonesia. Karakteristik wilayah yang heterogen dengan ratusan buah pulau menjadikan propinsi ini unik dari wilayah-wilayah lain. Kondisi alam yang didominasi lautan seharusnya merupakan kekuatan atau potensi local (local specific) bagi pengembangan wilayah yang berbasis pada kearifan lokalnya.

Berbatasan dengan laut Seram pada bagian utara, laut Indonesia dan laut Arafuru pada bagian selatan, bagian timur berbatasan dengan Propinsi Papua Barat dan bagian barat berbatasan dengan Pulau Sulawesi. Secara keseluruhan luas wilayahnya adalah seluas $581.378 \mathrm{~km}^{2}$, dan luas wilayahnya 90 persen merupakan lautan seluas $527.191 \mathrm{~km}^{2}$. Dengan kondisi lautan yang demikian luasnya maka propinsi Mauku berpeluang untuk dapat berinteraksi dengan wilayah diluarnya.

Secara spesifik pulau-pulau yang ada di Maluku merupakan pulau-pulau yang mengelompok secara bersamaan dan memiliki karakteristik yang heterogen. Karakteristik yang saling berbeda antara satu pulau dengan pulau lainnya disebabkan oleh perbedaan aspekgeografisi, fisik, iklim, sosial, budaya dan etnis serta tahapan perkembangan ekonomi wilayahnya. Secara administarasi, propinsi Maluku terdiri dari 9 Kabupaten dan 2 Kotamadya, yaitu:

Tabel 2.

\begin{tabular}{cll}
\hline No & \multicolumn{1}{c}{ Kabupaten/Kota } & \multicolumn{1}{c}{ Ibukota } \\
\hline 1 & Maluku Tenggara Barat & Saumlaki \\
2 & Maluku Tenggara & Langgur \\
3 & Maluku Tengah & Masohi \\
4 & Buru & Namlea \\
5 & Kepulauan Aru & Dobo \\
6 & Seram Bagian Barat & Piru \\
7 & Seram Bagian Timur & Bula \\
8 & Maluku Barat Daya & Tiakur \\
9 & Buru Selatan & Namrole \\
10 & Kota Ambon & Ambon \\
11 & Kota Tual & Tual \\
\hline
\end{tabular}

Masing-masing wilayah diatas merupakan bagian dari gugus pulau yang tersebar dari utara sampai ke selatan dengan luas wilayah yang berbeda baik dalam kondisi, karakteristik geografis serta alamnya yang heterogen dengan kata lain potensi atau kapasitas antarwilayah berbeda diantara wilayah-wilayah tersebut. Karakter wilayah yang berbeda-beda inilah yang mengakibatkan perkembangan pembangunan di beberapa wilayah di Propinsi Maluku melakukan pemusatan kegiatan ekonomi, sosial bidaya dan administasi pada pulau-pulau besar saja. Hal inilah yang 
mengakibatkan sumber-sumber pertumbuhan, pola persebaran kegiatan ekonomi, serta adanya gejala aglomerasi kegiatan ekonomi hanya pada wilayah-wilayah tertentu saja.

Berdasarkan data registrasi kependudukan, jumlah penduduk Propinsi Maluku tahun 2016 berjumlah 1.715.548 jiwa dengan persebaran yang tidak merata karena adanya konsentrasi penduduk pada wilayah-wilayah tertentu terutama pada wilayah pusat kota dan terkonsentrasi pada wilayah-wilayah tertentu saja. Karena tidak meratanya persebaran penduduk, menyebabkan ada wilayah-wilayah yang sedikit penduduk dengan kehidupan yang tidak layak (miskin). Data BPS Propinsi Maluku selama tahun 2012 ada 333.600 jiwa penduduk miskin, tahun 2013 sebanyak 315.200 jiwa, dan tahun 2014 sebesar 307.000 jiwa penduduk miskin.

Kemiskinan merupakan salah satu faktor utama penyebab terjadinya tindak pidana perdagangan orang di Propinsi Maluku. Disamping itu, kebutuhan ekonomi yang terus mengalami peningkatan ditambah angka pengangguran yang terus bertambah setiap tahun serta semakin sedikitnya lapangan pekerjaan menjadi beberapa faktor yang menyebabkan terjadinya tindak pidana perdagangan orang.

\section{b. Penanggulangan Perdagangan Orang di Maluku}

Perdagangan orang telah meluas dalam bentuk jaringan kejahatan yang terorganisasi dan tidak terorganisasi, baik bersifat antar negara maupun dalam negeri, sehingga menjadi ancaman terhadap masyarakat, bangsa dan negara serta terhadap norma-norma kehidupan yang dilandasi penghormatan terhadap hak asasi manusia. pada umumnya yang menjadi korban tindak pidana perdagangan orang adalah perempuan dan anak-anak. Bentuk-bentuk tindak pidana perdagangan orang yang paling banyak terjadi antara lain:

1). Pengiriman TKI (Tenaga Kerja Indonesia) keluar negeri tanpa adanya dokumen resmi atau dokumen yang dipalsukan dengan berbagai kedok seperti misi kebudayaan;

2). Penempatan tenaga kerja di dalam negeri untuk dieksploitasi secara seksual;

3). Penyelenggaraan perkawinan antar negara melalui pemesanan dimana pengantin perempuan tidak mengetahui kondisi sebenarnya dari calon suami;

4). Perekrutan perempuan dan anak perempuan untuk objek prostitusi dan pornografi;

5). Perekrutan tenaga kerja dengan upah minim, kondisi kerja yang mengancam kesehatan tubuh dan mental serta moral; dan

6). Pengangkatan anak atau bayi yang dilakukan tanpa proses yang benar.

Selain itu, ada beberapa faktor yang memiliki korelasi dengan tindak pidana perdagangan orang yaitu:

1). Struktur masyarakat yang masih menempatkan perempuan sebagai warga kelas 2 yang menimbulkan genderbased discrimination dan gender based violence. Yang menyebabkan kemiskinan perempuan dan mendorong perempuan masuk perangkap perdagangan orang;

2). Struktur patriakhal yang mendukung pola pendidikan perempuan menjadi submissive mengutamakan kehormatan dan kepentingan keluarga berakhir pada pengorbanan diri dalam perdagangan orang;

3). Terbatasnya sumber keuangan menyebabkan suburnya industri seks; dan

4). Terjadinya berbagai konflik yang menempatkan perempuan dan anak menjadi rentan, kehilangan perlindungan, keamanan dan hak asasi lainya.

Di Propinsi Maluku sendiri, bentuk tindak pidana perdagangan orang yang terjadi antara lain perekrutan tenaga kerja dengan upah minim yang ditempatkan pada sektor perkebunan kelapa sawit maupun perkebunan coklat bahkan perikanan yang melibatkan tenaga kerja asing, tumbuh suburnya industri prostitusi yang dilakukan oleh perempuan dan anak perempuan usia 14-23 tahun. Kota Ambon merupakan daerah yang paling banyak terjadi tindak pidana perdagangan orang dengan jenis prostitusi dan perekrutan tenaga kerja di bidang perikanan yang sasarannya kepada 
nelayan baik lokal maupun luar negeri. Berikutnya Kabupaten Kepulauan Aru khususnya daerah Benjina, dengan jenis perektrutan tenaga kerja dibidang perikanan yang berupah minim dari berbagai negara seperti Myanmar, Thailand, Kamboja. Untuk sektor perkebunan khususnya perkebunan kelapa sawit maupun perkebunan coklat, tenaga kerja dengan upah minim banyak terjadi di daerah Seram Bagian Barat. Umumnya penduduk daerah setempat yang dijadikan sebagai tenaga kerja. Sekitar 620 orang diduga menjadi korban tindak perdagangan orang di Ambon dan baru 13 yang teridentifikasi.

Maraknya tindak pidana perdagangan orang yang terjadi di Maluku, membutuhkan penanggulangan yang tepat. Melalui jalur hukum pidana, saat ini Indonesia telah memiliki norma hukum yang mengatur tindak pidana perdagangan orang yang diatur dalam Undang-Undang Nomor 21 Tahun 2007 tentang Pemberantasan Tindak Pidana Perdagangan Orang. Ancaman pidana yang cukup berat pun menanti para pelaku. Meskipun telah memiliki undang-undang yang mengatur, tidak mudah untuk melakukan pemberantasan tindak pidana perdagangan orang di Maluku. hal ini dikarenakan ketertutupan masyarakat untuk menyampaikan dugaan terjadinya tindak pidana perdagangan orang yang terjadi. Selain ketertutupan terhadap informasi, ancaman keselamatan sebagai saksi maupun korban tindak pidana perdagangan orang yang dikenal dan memiliki hubungan kekerabatan keluarga menjadi kendala.

Ketika ada laporan tentang dugaan terjadinya tindak pidana perdagangan orang, para korban akan ditampung yang disediakan oleh Dinas Sosial dan kemudian akan dikembalikan ke daerah asal. Sedangkan untuk pelaku, dalam kasus perdagangan orang di Benjina 8 orang ( 3 orang manager warga negara Indonesia dan 5 Kapten warga Thailand) dijatuhkan pidana penjara.

Secara struktur, koordinasi antara aparat penegak hukum (kepolisian), dinas ketenagakerjaan Propinsi Maluku, Dinas Sosial Propinsi Maluku sangat diperlukan dalam pencegahan dan penanggulangan terhadap pelaku maupun korban tindak pidana perdagangan orang. Kurangnya koodinasi antara aparat penegak hukum maupun instasi-instansi yang terkait menyebabkan lambatnya penanganan terhadap tindak pidana perdagangan orang yang terjadi di Maluku. Kurangnya pengetahuan penduduk di Propinsi Maluku tentang tindak pidana perdagangan orang, menyebabkan tindak pidana khusus ini sering diabaikan bahkan dianggap tidak pernah terjadi. Sebagai daerah dengan julukan "negeri raja-raja" penanggulangan tindak pidana perdagangan orang dilakukan dengan melibatkan para pemuka/tokoh masyarakat khususnya perangkat negeri (raja, badan saniri, dll) sebagai 'perpanjangan tangan' pemerintah untuk melakukan upaya-upaya pencegahan. Pemberian sosialisasi kepada serta pengetahuan tentang tindak pidana perdagangan orang diberikan sebagai bentuk perlindungan kepada masyarakat khususnya warga di negerinegeri (desa) yang jauh dari kota bahkan yang sulit dijangkau dengan akses penghubung jalan darat.

Sedangkan, melalui sarana non-penal, penanggulangan tindak pidana perdagangan dilakukan melalui kegiatan penyuluhan hukum maupun sosialisasi yang dilakukan baik oleh para aktivis perempuan dan anak, para akademisi, maupun para tokoh-tokoh agama di Propinsi Maluku. Penyuluhan hukum yang diberikan tidak hanya untuk orang dewasa tetapi juga menjangkau anakanak usia sekolah. Selain itu, keterlibatan tokoh-tokoh adat dalam pencegahan dan penanggulangan tindak pidana perdagangan orang sangat membantu.

\section{KESIMPULAN}

Berdasarkan uraian yang telah dilakukan dalam pembahasan, dapat disimpulkan bahwa ada 3 (tiga) kabupaten/kota yang menjadi tempat terjadinya tindak pidana perdagangan orang di Maluku yaitu Kota Ambon, Kabupaten Seram Bagian Barat dan Kabupaten Kepulauan Aru. Bentuk tindak pidana yang terjadi antara lain perekrutan tenaga kerja dengan upah yang mini pada sektor perkebunan (kelapa sawit maupun coklat), sektor perikanan maupun industri prostitusi yang berkembang subur dan terselubung. 
Oleh karena itu, penanggulangan terhadap tindak pidana perdagangan orang dapat dilakukan melalui jalur hukum pidana, yang dalam penerapannya memiliki sanksi pidana yang cukup berat bagi para pelaku, selain itu koordinasi antara aparat penegak hukum maupun instasi yang terkait dalam pemberantasan tidak pidana perdagangan orang sangat penting. keterlibatan masyarakat maupun tokoh masyarakat dalam negeri-negeri di Maluku berperan penting dalam pencegahan tindak pidana ini.

Melaui jalur non-penal, dilakukan upaya advokasi yang melibatkan seluruh masyarakat, tokoh agama maupun anak-anak usia sekolah dalam bentuk sosialisasi maupun penyuluhan hukum yang dilakukan baik oleh instansi terkait maupun para akademisi. Penanggulangan tindak pidana perdagangan orang tentu memiliki kendala-kendala, seperti akses yang sulit untuk menjangkau tenpat terjadinya tindak pidana, kurangnya koordinasi aparat penegak hukum maupun instansi terkait serta keterbukaan terhadap informasi dugaan terjadi tindak pidana perdagangan orang oleh masyarakat yang ditutupi.

\section{REFERENSI}

Arief, B.N (2001). Masalah penegakan hukum dan kebijakan penanggulangan kejahatan. Bandung: PT. Citra Aditya Bakti.

Arie, B.N. (2011). Bunga rampai kebijakan hukum pidana. Jakarta: PT. Kencana Prenada Media Group

Badan Pusat Statistik. (2014). Sosial Kependudukan Propinsi Maluku. Ambon, Maluku, Indonesia.

H. Nurhenny. (2010). Tindak pidana perdagangan orang kebijakan hukum pidana dan pencegahannya. Jakarta: Sinar Grafika.

Munthe, R. (2015). Perdagangan orang (trafficking) sebagai pelanggaran hak asasi manusia. Jurnal Pendidikan Ilmu-Ilmu Sosial, 184-192.

Marzuki, P.H. (2007). Penelitian hukum. Jakarta: PT. Kencanan Prenada Media Group.

Sugiyono . (2009). Metode penelitian kuantitatif, kualitatif dan $r \& d$. Bandung: PT. Alfabeta. 